\title{
A Critical Misdiagnosis: How Courts Underestimate the Anticompetitive Implications of Hospital Mergers
}

\author{
Jennifer R. Conners $\dagger$
}

\section{TABLE OF CONTENTS}

Introduction

I. Understanding Hospital Mergers and Their Impact on Consumers .. 547

A. The Rush to Consolidate....................................................... 547

B. The Dangers of Hospital Mergers............................................ 548

I. Market Power ................................................................. 550

2. Effects of Hospital Consolidation on Related Industries ..... 553

3. Ramifications for Indigent and Female Patients .................. 554

C. Government Response to Merger Activity in the Hospital

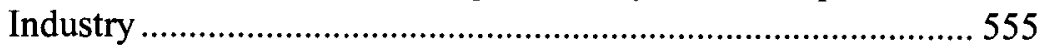

II. Introduction to Relevant Antitrust Principles.................................558

A. The Clayton Act................................................................... 558

B. The Anticompetitive Effects Analysis .................................... 558

III. Critique of Courts' Antitrust Analysis .............................................. 561

A. Flaws in the Analysis of the Relevant Market .......................... 562

1. Defining the Product Market............................................. 562

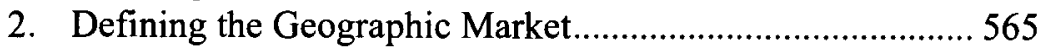

B. Underestimation of the Merged Entity's Market Power............. 567

C. Failure to Include Nonprice Competition in Analysis ................ 570

D. Overestimation of Mitigating Factors ....................................... 571

1. Nonprofit Status ............................................................... 571

2. Post-merger Community Control ...................................... 573

IV. The Need for Stricter Antitrust Analysis....................................... 573

A. The Continued Role of Courts .............................................. 573

B. Alternatives to Judicial Action ............................................. 574

Copyright $\bigcirc 2003$ California Law Review, Inc. California Law Review, lnc. (CLR) is a California nonprofit corporation. CLR and the authors are solely rcsponsible for the content of their publications.

$\dagger \quad$ J.D. Candidate, School of Law, University of California, Berkeley (Boalt Hall), 2003; B.S., University of California, Berkeley, 1997. 1 would like to thank Professor A. Edlin, D. Larson, H. Weaver, H. Rosmarin, X. Wu, and the editors and staff of the California Law Review for their valuable contributions to previous drafts. 1 am especially grateful to Dcrek, and to my parcnts, Meg and Bill, for unfailing encouragement during this endeavor and through law school. I dedicate this Comment to two lifelong educators: Eileen B. Conners and Sydney R. Parker. 
1. State Regulation of Hospital Mergers ............................... 574

2. Cooperative Efforts Between Hospitals ............................. 575

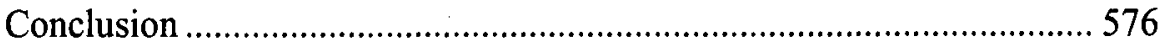




\title{
A Critical Misdiagnosis: How Courts Underestimate the Anticompetitive Implications of Hospital Mergers
}

\author{
Jennifer R. Conners
}

Antitrust challenges to hospital mergers have been largely unsuccessful in recent years. As a result, there has been substantial consolidation in the hospital industry. The resulting loss of competition often leads to dire consequences for consumers in terms of increased prices and decreased services. It is therefore important to examine the reasons why merger challenges frequently fail in court. Upon closer scrutiny, four types of court analytical errors emerge: First, courts can misconstrue the relevant market by misunderstanding the component product or geographic markets. Second, courts can underestimate the merged entity's market power. Third, courts can fail to include relevant nonprice competition in the analysis of the anticompetitive effects of the merger. Finally, courts can overestimate the value of mitigating factors, such as nonprofit status or the existence of a community commitment to keep prices low after a merger. The judiciary will continue to play a substantial role in the evaluation of hospital mergers. Therefore, this Comment argues that it is essential for courts to take a stricter approach to merger analysis in order to protect consumers from the harms associated with the absence of competition.

\section{INTRODUCTION}

In many parts of the country, substantial hospital consolidation has resulted in consumers paying higher hospital prices yet receiving lower quality of care. One reason for this trend may be the failure of courts to apply antitrust law correctly to hospital mergers. The purpose of antitrust law is to protect the consumer by promoting free competition, which fosters lower prices and higher quality. However, in the past decade, the Department of Justice and the Federal Trade Commission (collectively "the government") have been largely unsuccessful in persuading courts to apply federal antitrust law ${ }^{1}$ to block hospital mergers that raise competitiveness concerns. As a result, merger activity among hospitals has led to consolidated hospital ownership and powerful multihospital systems. In many

1. The main federal antitrust provision that applies to hospital mergers is section 7 of the Clayton Act, 15 U.S.C. $\S 18(2000)$. 
communities, the merged entities have accrued considerable market power with deleterious ramifications for both price and nonprice competition.

The hospital industry constitutes a substantial and growing part of the U.S. economy: In 2001, health care spending rose to $\$ 1.4$ trillion, an increase of $8.7 \%$ over the previous year. ${ }^{2}$ A substantial part of this increase was the result of growth in the hospital industry. ${ }^{3}$ While small independent hospitals were once the norm, the industry has undergone substantial consolidation over the past three decades, giving rise to larger facilities and multihospital systems. ${ }^{4}$ In 1980 , approximately $32 \%$ of community hospitals were part of larger networks. ${ }^{5}$ Over the next eighteen years, this percentage rose to approximately $57 \%$, predominantly through mergers. ${ }^{6}$ In 1995 , for example, approximately $11 \%$ of the hospitals in California declared their intent to merge. ${ }^{7}$ As a result of these mergers, more than onethird of California hospitals belonged to one of six networks by $1998 .{ }^{8}$ These networks have become powerful entities with substantial bargaining power in the health care field. For example, HCA, the largest hospital company in the United States, operates 189 general acute-care hospitals and 76 outpatient surgery centers in 24 states. HCA's reported 1999 pre-tax income from continuing operations was \$I.2 billion. ${ }^{9}$ The second largest hospital system, Tenet Healthcare, has grown from fifty hospitals in 1995 to 115 today..$^{10}$ Tenet owns forty hospitals in California alone, making it the largest hospital operator in the state. ${ }^{11}$

A close analysis of recent antitrust cases indicates that courts may be making antitrust exceptions for hospital mergers. In analyzing why hospitals are being treated so leniently under antitrust law, this Comment argues

2. Centers for Medicare \& Medicaid Serviees, Health and Human Services, Report Details National Health Care Spending Increases in 2001 (Jan. 8, 2003), at http://www.cms.hhs.gov/media/ press/release.asp?Counter $=639$.

3. Id.

4. See Joanne Spetz et al., The Growth of Multihospital Firms in California, 19 Health AfF. 224 (2000) (detailing the rapid rise of multihospital nctworks); Tom Abate, St. Luke's Agrees to Be 30th Link in Sutter Chain, S.F. CHRON., Oct. 27, 2000, at B1 (commenting on the acquisition of the last independent hospital in San Francisco by the Sutter Hospital chain).

5. Spencer Rich, Health Care: An Era of Consolidation, 32 NAT'L J. 2296, 2297 (2000) (citing a statistic from the American Hospital Association).

6. Id. See also Bruce Japsen, An Off Year for Consolidation, Mod. HealthCARE, Jan. 12, 1998, at 40-48 (stating that the merger activity between 1994 and 1997 was especially intense, reaching record-setting levels of more than 600 mergers per year).

7. Spetz et al., supra note 4, at 224 (noting that in 1995, 43 of California's 400 hospitals initiated mergers and purchases).

8. Id. at 225 (describing the extent to which California hospitals have consolidated and noting that in the most concentrated urban hospital market, Sacramento, only $4 \%$ of the hospitals remain independent).

9. High-grade Corporate Bond Research (Nov. 17, 2001) (on file with author) (also noting that "HCA has a dominant business position in the hospital industry in key regions around the country").

10. Don Lee, Closures Put Big Hospital Chains Under Microscope, L.A. Times, Aug. 22, 2002, at Al.

11. Id. 
that courts may be making several errors in the process of analyzing the anticompetitive effects of hospital mergers. These errors can lead courts to underestimate the anticompetitive potential of hospital mergers and fail to enjoin those mergers that substantially lessen competition. Part I of this Comment describes what is at stake for consumers and argues that proper antitrust analysis is especially crucial with regard to hospital mergers because alternatives, such as state regulation, are generally unsuccessful. Part II introduces the principles of antitrust law that provide the framework for merger analysis under section 7 of the Clayton Act. It then analyzes the outcome of challenges brought by the government under section 7. Part III critiques how courts currently apply antitrust law to hospital mergers. Part IV explores available alternatives to court challenges and argues that the insufficiency of these alternatives necessitates stricter enforcement of antitrust law by courts.

\section{I}

\section{Understanding Hospital Mergers and Their ImPaCt on Consumers}

\section{A. The Rush to Consolidate}

Advocates of hospital mergers and their opponents disagree about which forces are driving the continuing trend toward consolidation in the hospital industry. Hospital executives point to increasing financial pressures as the impetus for such mergers. ${ }^{12}$ There is significant support for this argument. First, some hospitals are experiencing a decrease in the number of patients and thus are operating at a lower capacity. ${ }^{13}$ Second, the market formerly enjoyed exclusively by hospitals has been invaded by outpatient surgery centers, birthing centers, and other specialty providers, which have established themselves as successful competitors for services traditionally provided by hospitals. ${ }^{14}$ Third, increased competition among hospitals for fewer patients tends to create costly duplication of equipment: If one hospital gets state-of-the-art technology, other hospitals experience pressure to respond by purehasing similar equipment, even if the demand is not

12. See, e.g., State v. Sutter Health Sys., 130 F. Supp. 2d 1109, 1115-17 (N.D. Cal. 2001) (detailing the dire finaneial situation that Sutter was facing and using this evidence to explain Sutter's desire to merge).

13. See, e.g., United States v. Mercy Health Servs., 902 F. Supp. 968, 972 (N.D. Iowa 1995), vacated as moot on unrelated grounds by 107 F.3d 632 (8th Cir. 1997). After submission of the appeal, one of the appellees announced that it was abandoning the attempt to merge. The Eighth Circuit then held that the case was moot on the grounds that it was no longer a case or controversy. However, courts and commentators continue to cite to Mercy Health for its reasoning. See, e.g., United States v. Long Island Jewish Med. Ctr., 983 F. Supp. 12I, 136, I37, 142, 143 (E.D.N.Y. 1997); Peter J. Hammer \& William M. Sage, Antitrust, Health Care Quality, and the Courts, 102 Colum. L. Rev. 545, 545 (2002).

14. Mercy Health Servs., 902 F. Supp. at 974. 
sufficient to justify the cost. ${ }^{15}$ Fourth, consolidation in related industries, such as insurance and drug manufacturing, has put hospitals at a disadvantage in negotiations for higher compensation for patient care and lower drug prices. ${ }^{16}$ Finally, high facility and equipment maintenance costs create further incentives for hospitals to find ways to minimize expenses. ${ }^{17}$

Mergers between hospitals have the potential to relieve many of these financial pressures. ${ }^{18}$ The merged entity can realize savings from sharing equipment, staff, and other costs. ${ }^{19}$ Mergers may enable hospitals to eliminate inefficiencies in a number of other ways as well. For example, two hospitals could pool their patients and redistribute them between the existing facilities in a more cost-effective manner. ${ }^{20}$ The merger process also presents the opportunity to create better management by realigning the company's operations or selecting administrators with the determination to implement painful budget and staff cuts. ${ }^{21}$ Proponents of mergers contend, and many courts agree, that these cost-saving measures decrease hospitals' operating costs and ultimately translate into lower health care costs for consumers, including insurance companies, employers, and uninsured patients. ${ }^{22}$

\section{B. The Dangers of Hospital Mergers}

Commentators argue, however, that consolidation is not a legitimate response to financial pressure but is instead driven by hospitals' desire to obtain increased bargaining power against growing managed care and

15. In re Adventist Health Sys./West, No. 9234, 1992 WL 696729 at *6 (F.T.C. Dec. 9, 1992) (citing the testimony of a doctor discussing the problem with duplication of services: "[T]hey're competing with one another, trying to duplicate services. This hospital gets a CAT scan, that hospital has to have a CAT scanner. This hospital gets orthopedic equipment, that hospital has to have orthopedic equipment.").

16. See, e.g., Rich, supra note 5, at 2297 (discussing the market power obtained by some pharmaceutical companies through eonsolidation and citing the example of a company that cornered the market on a key ingredient needed by two competing companies and raised prices on products by as much as $3300 \%$ virtually overnight).

17. See, e.g., Spetz et al., supra note 4, at 226 (noting that California Senate Bill 1953, requiring seismic upgrades by 2008 , will cost hospitals an estimated $\$ 10-24$ billion).

18. See generally Richard A. Brealey \& Stewart C. Myers, Principles of Corporate FinANCE 817-24 (4th ed. 1991).

19. Id. at 821 .

20. Id. at 821,823 .

21. Id. at 823-34.

22. See United States v. Long lsland Jewish Med. Ctr., 983 F. Supp. 121, 148 (E.D.N.Y. 1997) (finding that "efficiencies ... would be achieved by the proposed merger" as a result of "a reduction in personnel in various departments of both hospitals, including the financial departments and pain management; some reduction in the cost of clinical laboratory services and medical supplies; claims recovery costs and utilities; laundry costs; in-house consulting services; and computer and information services"); FTC v. Butterworth Health Corp., 946 F. Supp. 1285 (W.D. Mich. 1996) (finding that efficiencies gained in merger would result in benefits to consumers). 
pharmaceutical companies and to compete with larger hospital networks. ${ }^{23}$ As one hospital executive explained to investors, "[w]e've built large, strong networks of hospitals in key markets . . . We truly have leverage, and we're learning how to use it effectively." ${ }^{24}$ This increased power could threaten the ability of providers (physicians, suppliers, or anyone else who contracts with hospitals) to receive fair compensation for their services.

Further, rapid consolidation of hospital ownership has generated significant concern and commentary from industry and health care experts and the public, ${ }^{25}$ who are concerned that a subsequent loss of competition between hospitals will not generate the anticipated savings but will instead produce dire consequences for patients; ${ }^{26}$ Critics claim that, despite hospitals' efficiency argument, the cost of care is likely to increase as hospital systems grow in size and obtain more power over price. ${ }^{27}$ In addition, opponents of hospital mergers warn that indigent people and women will suffer reduced access to health care. For example, when nonprofit hospitals merge with for-profit hospitals, the merged entity may drop services for the poor, and when Catholic and non-Catholic hospitals merge, the merged entity may drop controversial reproductive-health and family-planning services for women. ${ }^{28}$ Finally, health care experts argue that mergers may detract substantially from the quality of patient care by eliminating the

23. See, e.g., David Dranove et al., Is Managed Care Leading to Consolidation in Health-Care Markets?, 37 Health SeRvices Res., 573, 574 (2002) (observing that "providers may consolidate to improve their bargaining power and opportunities to secure contracts at favorable rates"); Yochi $\mathrm{J}$. Dreazen, Why the Sudden Rise in the Urge to Merge and Form Oligopolies?, WALL St. J., Feb. 25, 2002, at Al (quoting one observer's sentiment that "the rewards for getting bigger" have increased while "antitrust cops," such as regulators and judgcs, "seem less antagonistic" to mergers).

24. Barbara Martinez, With New Muscle, Hospitals Squeeze Insurers on Rates, THE WALL Street J., Apr. 12, 2002, at Al (quoting Jeffrey Barbakow, chief executive of Tenet Healthcare Corporation, the second largest hospital chain).

25. See generally Jonathan B. Baker, The Antitrust Analysis of Hospital Mergers and the Transformation of the Hospital Industry, 51 LAW \& ConTemP. ProBs. 93 (1988); Spetz et al., supra note 4, at 224; Liz Kowalczyk, Hospitals Cast Wary Eye at Partners: Health Care Network's Negotiating Clout, Expanding Market Share Spur Concerns that Firm Is Too Big, BOSTON GLOBE, Apr. 27,2001 , at D1.

26. See, e.g., Steffie Woolhandler \& David U. Himmelstein, Costs of Care and Administration at For-Profit and Other Hospitals in the United States, 11 New ENG. J. MED. 336, 769-74 (1997) (expressing concern that multihospital systems may threaten patient care, remove charitable institutions from local control, and place too much emphasis on the financial "bottom line").

27. See, e.g., Gary J. Young et al., Community Control and Pricing Patterns of Nonprofit Hospitals: An Antitrust Analysis, 25 J. Health POL. PoL'y \& L. 1051 (2000) (arguing that even nonprofit hospitals, which would bc expected to be the least profit-oriented, tend to raise priees after a merger).

28. See, e.g., Judith C. Applebaum \& Jill C. Morrison, Hospital Mergers and the Threat to Women's Reproductive Health Services: Applying the Antitrust Laws, 26 N.Y.U. Rev. L. \& Soc. CHANGE 1 (2000) (identifying the anticompetitive effects of religiously affiliated hospital mergers on women's health services); Martha Minow, Partners, Not Rivals?: Redrawing the Lines Between Public and Private, Non-Profit and Profit, and Secular and Religious, 80 B.U.L. Rev. 1061, $1069-70$ (2000) (discussing ramifications of mergers for women and indigent people). 
incentive for hospitals to compete over nonprice factors such as better nursing, more specialists, and other products and services.

\section{Market Power}

Depending on the extent to which a hospital network dominates a certain geographic region, a decrease in the number of competing hospitals provides health plans and patients with fewer alternatives. ${ }^{29}$ If health plans and patients have few alternatives, or no alternatives, then the merged entity is likely to enjoy greater market power. In certain regions, this likelihood has become reality: Mergers have resulted in enormous market power, creating the widespread perception that hospital networks have grown "too large and too powerful." 30

The Partners network exemplifies this consolidation phenomenon and the resulting market power. This network controls eight hospitals and has more than 5000 employees. It has captured $20 \%$ of the market share of overnight patients in Eastern Massachusetts and $35 \%$ of the market share of overnight patients in Boston. ${ }^{31}$ Partners' sheer size gives the network substantial power to raise prices for consumers. A recent example highlights this power: In interactions between Partners and health plans, Partners was able to win double-digit rate increases from one health plan, and the network is expected to obtain $25-30 \%$ increases from another. ${ }^{32}$ Partners justifies these increases as necessary for them to break even financially. ${ }^{33}$ However, regardless of whether or not rate increases are financially justified, the fact remains that Partners has a "near lock on entire regions like the North Shore and western suburbs, making it impossible for health plans to reject rate increase requests or eliminate Partners from their networks." ${ }^{34}$ Partners' apparent ability to dictate the prices that health plans must pay frustrates the purpose of antitrust law, which is to protect free

29. This argument appears, at least implicitly, in every ease where the government challenges a merger. For example, in FTC v. Butterworth Health Corp., the government argued that "[a] transaction resulting in a high concentration of market power and creating, enhancing, or facilitating a potential that such market power could be exercised in anticompetitive ways is presumptively unlawful." $946 \mathrm{~F}$. Supp. 1285, 1294 (W.D. Mich. 1996) (quoting FTC v. Univ. Health, 938 F.2d 1206, 1218 (1 th Cir. 1991)).

30. Kowalczyk, supra note 25. See also Martin Gaynor, Don't Let UPMC Grab Children's Hospital, PITTSBUrgh Post GazeTte, July 1, 2001, at E1 (criticizing a dominant hospital's acquisition of a renowned children's hospital as being a "disaster in waiting" because it would give the merged entity too much market power); Don Lee, Closures Put Big Hospital Chains Under Microscope, L.A. TIMES, Aug. 22, 2002, at Al (describing community conccrns regarding the purchase of smaller community hospitals by larger chains, which resulted in increased market power).

31. Kowalczyk, supra note 25.

32. Id. (referring to contracts with Tufts Health Plan and Harvard Pilgrim Health Care).

33. Id.

34. Id. 
competition on the premise that it is the best way to ensure low prices and high quality for consumers. ${ }^{35}$

Mergers involving acquisition of an "essential facility," such as a renowned children's hospital, raise similar concerns about market power. ${ }^{36}$ Health plans may have no choice but to contract with the network that is acquiring the facility, even if prices increase sharply, because there is no viable alternative. This problem also arises when consolidation results in a situation where only one or two hospitals in a region provide emergency services. ${ }^{37}$ Therefore, if there are no legitimate alternatives within a reasonable geographic range, health plans have no choice but to contract with the existing hospitals for emergency or essential facilities. Insurers and competitors are significantly disadvantaged by their loss of bargaining power, which gives hospitals greater leeway to set high prices or to reduce quality. ${ }^{38}$

Even in cases where courts have recognized the huge market power that would be enjoyed by a newly merged hospital, they have downplayed the impact of such power and focused instead on whether the merger will have any actual anticompetitive effects. ${ }^{39}$ This focus means that even where a court determines that the merged entity will enjoy substantial market power, the court often will consider how the merged entity is likely to act upon this market power and ask whether there will be any real anticompetitive results. If the court finds that there will be no anticompetitive results, the court might ignore the fact that the entity will have large market power. This tendency to downplay or negate the implications of the market power held by a merged hospital indicates that courts view consolidation within the hospital industry as somehow different from consolidation in other industries. Despite the fact that Congress has not exempted hospitals from antitrust laws, ${ }^{40}$ courts' treatment of hospital mergers reflects a

35. See infra Part II (discussing antitrust principles).

36. See, e.g., Gaynor, supra note 30, at E1 (identifying the children's hospital as an "essential facility" and arguing that "UPMC's acquisition of Children's will greatly increase its power" to the detriment of health insurers, employers, and quality of care).

37. It is not difficult to find mergers which would decrease the number of competitors to one. See, e.g., Columbus Hosp./Mont. Deaconess Med. Ctr. Closing Letter, F.T.C. File No. 951-0117 (June 28,1996 ) (involving the only two general acute care hospitals in Great Falls, Montana); In re Local Health Sys., 120 F.T.C. 732 (1995) (involving the only two general acute care hospitals in Port Huron, Michigan); Parkview Episcopal Med. Ctr./St. Mary-Corwin Hosp. Preliminary Injunction, File No. 9310025 (Jan. 31, 1994) (involving the only two general acute care hospitals in Pueblo County, Colorado).

38. See Gaynor, supra note 30 (arguing that acquisition of the renowned Children's Hospital will give hospital network a substantial advantage because there is not a reasonable alternative).

39. See, e.g., FTC v. Butterworth Health Corp., 946 F. Supp. 1285, 1302 (W.D. Mich. 1996) (considering the antitrust implications of a merged entity which would control $47-65 \%$ of the acute care inpatient hospital services in the county).

40. The legislature has exempted certain areas from antitrust regulation. For example, the lvy League schools have been permitted to share scholarship information with each other without incurring antitrust liability. See Kim Clark, Paying for College, U.S. News \& WoRLD REP., Sept. 30, 2002, at 88. 
perception that, for various reasons, hospitals will not abuse their power over price. $^{41}$

However, studies and industry commentary indicate that the hospital industry does not differ from other industries in this respect and that market power in hospitals has led to price increases, just as it would in other industries. ${ }^{42}$ For example, after combining hospitals in three Chicago suburbs, "the bulked-up Evanston Northwestern Healthcare [demanded] rate increases as high as $60 \%$ for selected services." 43 In a similar situation, a merged entity sought to raise rates as much as $50 \%$, despite the fact that approval for the merger was obtained by assuring federal regulators that the merger's cost savings would result in lower, not higher, prices. ${ }^{44}$

There is yet another reason to be wary of market power: Even if a merged entity does not immediately exercise its power over price, the potential for future increases has already been established and is likely to persist given the substantial barriers to entry. Barriers to entry are factors that prevent other potential competitors from entering the market to compete. In the hospital context, barriers to entry include the cost of acquiring or building a facility, the cost to equip it with supplies and staff, and the cost of maintenance. ${ }^{45}$ The high cost of starting a hospital makes it very difficult for outsiders to enter the hospital market to become competitors, even if existing hospitals raise prices. Furthermore, unless there is a sharp population increase in a geographic area, the patient base is unlikely to support another hospital, especially if the lack of demand has already been identified as a financial pressure in the industry. Therefore, once a hospital acquires market power, it is likely that the hospital will retain market power. ${ }^{46}$ Despite this concern, a recent study found that only I $0 \%$ of courts that reviewed mergers even considered the anticompetitive barriers to

The rationale for this exception was that competition would produce the wrong result in this limited circumstance and therefore antitrust laws should not apply.

41. Mitigating factors cited by courts include nonprofit status and community control. See, e.g., Butterworth Health Corp., 946 F. Supp. at 1297 (finding that "the involvement of prominent community and business leaders on the boards of these hospitals can be expected to bring real accountability to price structuring"). For a detailed discussion of these factors, see infra Part 111.D.

42. See, e.g., Young et al., supra note 27 at 1073 (finding that both large network hospitals and nonprofit hospitals show a tendency to raise prices after a merger); see also Dranove et al., Price and Concentration in Hospital Markets: The Switch from Patient-Driven to Payer-Driven Competition, 36 J.L. \& ECON. 179 (1993); Glenn J. Melnick et al., The Effects of Market Structure and Bargaining Position on Hospital Prices, 11 J. Health Econ. 217, 229 (1992).

43. See, e.g., Hospital Merger Trauma: Rising Health Care Rates, Crain's ChI. Bus., Feb. 5 , 2001, at 10 [hereinafter Hospital Merger Trauma].

44. Id.

45. Consider the seismic upgrade requirements of California Senate Bill 1953 which are cstimated to impose "greater financial pressure on already tight hospital resources." Spetz et al., supra note 4 , at 228 .

46. But see United States v. Long Island Jewish Med. Ctr., 983 F. Supp. 121 , 149 (E.D.N.Y. 1997) (holding that there was no substantial barrier to cntry because many esteemed Manhattan hospitals were realistically poised to enter the Long Island market and act as competitors). 
entry. ${ }^{47}$ This low percentage indicates that courts underestimate the implications of barriers to entry.

\section{Effects of Hospital Consolidation on Related Industries}

Concern about consolidation in health care industries extends beyond the hospital industry. For example, Congress has scrutinized the "enormous consolidation" within the insurance industry and expressed concern that "mergers could eventually undermine competition, foster monopoly, and result in higher costs for patients." ${ }^{\prime 8}$ Increased consolidation within the pharmaceutical industry has also received criticism. Critics have attributed higher prescription drug prices to the large number of mergers between pharmaceutical companies in recent years. ${ }^{49}$ Like hospitals, insurance companies also complain they have suffered from higher prices due to the increased power of other related industries. ${ }^{50}$

Recent activity within the medical community indicates that the pressure to acquire bargaining power extends to doctors too. Responding to physicians' concerns that they have unequal bargaining power compared to insurance companies, the American Medical Association ("AMA") called for Congress to create an antitrust exemption for physicians. ${ }^{51}$ Congress responded with the Quality Health-Care Coalition Act of 1999, which sought "to ensure and foster continued patient safety and quality of care by making the antitrust laws apply to negotiations between groups of health care professionals and health plans and health insurance issuers in the same manner as such laws apply to collective bargaining by labor organizations under the National Labor Relations Act." 52 The AMA claims that insurance companies' substantial negotiating clout puts independent doctors at a disadvantage and that an exemption is needed to "level the playing field." 53

Given the interrelationship of these health care industries, it is clear that major changes in one affect the economic dynamics of the others. While the degree of interrelatedness explains the escalating merger frenzy in health care generally, it does not excuse the failure of the courts to enforce antitrust law to prevent this loss of competition. Many critics of

47. Peter J. Hammer \& William M. Sage, Antitrust, Health Care Quality, and the Courts, 102 Colum. L. Rev. 545, 581 (2002).

48. Rich, supra note 5, at 2296 (quoting Representative John Conyers Jr., D-Mich., the senior Democrat on the House Judiciary Committee, which oversees antitrust issues: "[W]e've seen enormous consolidation").

49. See, e.g., id. (explaining that the Federal Trade Commission (the "FTC") has investigated questionable drug-company practices, such as sudden price hikes of as much as $3300 \%$, following a merger).

50. See Hospital Merger Trauma, supra note 43, at 10 (detailing pressure on insurance companies by other industries).

51. See Rich, supra note 5, at 2297.

52. H.R. 1304, 106th Cong. (1999).

53. Id. 
multihospital systems recognize the interplay between the different players in the health care industry, ${ }^{54}$ and they use this dynamic to argue that the primary motivation behind the merger frenzy is "hospitals' desire for greater market power so that they can bargain for higher reimbursement rates from insurance companies." the purpose of antitrust law is to arrest concentration "in its incipiency." 56 So by failing to halt the accumulation of market power, the courts frustrate the purpose of antitrust law.

\section{Ramifications for Indigent and Female Patients}

Hospital mergers also pose a threat to specific groups of patients, particularly indigent and female patients. First, hospital mergers can have ramifications for the patients of nonprofit hospitals, ${ }^{57}$ which frequently provide vital care to those who cannot afford to pay for services. ${ }^{58}$ When a nonprofit merges with a for-profit hospital, its nonprofit status can be lost as a direct result of the merger agreement. The amount of charitable care available to the indigent population is therefore likely to decrease under the new, profit-oriented management. While charitable services may be dropped by the hospital, the need in the community persists. To the extent that indigent people are forced to seek care elsewhere, the load on other remaining providers is increased, affecting the remaining providers' ability to compete effectively with the newly merged entity.

Second, mergers involving religiously affiliated hospitals, especially Catholic hospitals, can threaten the availability of certain types of care to patients. ${ }^{59}$ Catholic hospitals do not provide church-prohibited services, such as performing abortions or distributing birth control. When a Catholic hospital merges with a non-Catholic hospital, the non-Catholic hospital often agrees to discontinue these services as a condition of the merger. ${ }^{60}$

54. See, e.g., Spetz et al., supra note 4 , at 224 .

55. Id. at 226 .

56. Brown Shoe Co. v. United States, 370 U.S. 294, 317 (1962). The Court held that Brown Shoe's purchase of Kinney Shoes violated section 7 of the Clayton Act. Although the merged entity only enjoyed $4.5 \%$ of the manufacturing market and $8 \%$ of the retail market for shoes, the Court emphasized that the purpose of antitrust law is to arrest concentration "in its incipiency," rather than waiting until an entity had achievcd substantial market power. $I d$. at 294 .

57. See, e.g., In re Columbia Hosp. Corp., 117 F.T.C. 587 (1994) (considering the ramifications of the proposed acquisition of a nonprofit by a for-profit hospital).

58. See Minow, supra note 28 , at 1070 (stating that "in many communities, Catholic health carc providers are literally life-savers; the Catholic health care mission includes a commitment to serve the poor that is increasingly rare and commendable as other public and private actors abandon those who are poor and lack insurance").

59. See Applebaum \& Morrison, supra note 28 (examining the impact of mergers on the availability of women's reproductive services in particular).

60. Id. at 6-7. 
This agreement can have serious implications for the availability of important reproductive services. ${ }^{61}$

\section{Government Response to Merger Activity in the Hospital Industry}

Initially, the response of the government to merger activity within the hospital industry was very deferential. In the I970s, the government generally overlooked hospital mergers, reflecting the viewpoint that competition in the health care industry was not an appropriate or necessary goal. ${ }^{62}$ There are several possible reasons why hospital mergers did not immediately arouse government suspicion. One possibility is that the caring, almost altruistic, nature of the hospital business may have differentiated hospitals from other profit-oriented business enterprises. Another is that when hospitals started to merge, they were not large enough to pose the risks that are associated with the powerful hospital systems of today. In fact, the government still takes little interest in the merger activities of smaller hospitals. For example, the government's 1994 guideline, Statements of Enforcement Policy and Analytical Principles Relating to Health Care and Antitrust ${ }^{63}$ crcatcs an antitrust safety zone. Smaller and older hospitals that fall within this zone are essentially exempt from antitrust scrutiny. This de facto exemption for smaller facilities indicates that the government does not perccive mergers involving smaller general acute care hospitals as posing a serious threat to competition.

In contrast to its hands-off approach to smaller hospital mergers, government challenges to larger hospital mergers have increased in recent years. ${ }^{64}$ These challenges have produced varying results. ${ }^{65}$ Frequently, the government fails to convince the court to issue a preliminary injunction to prevent a proposed merger. Courts have declined to enjoin mergers for a variety of reasons.$^{66}$ In some cases courts have held that the government

61. Id. at 10 (stating that "hospitals are important providers of other reproductive health services" in addition to abortion, such as sterilization procedures and emergency postcoital contraceptivcs for rape victims). There may also be repercussions for nonreproductive services such as counseling about HIV and end-of-life choiccs. See Kathleen M. Boozang, Deciding the Fate of Religious Hospitals in the Emerging Health Care Market, 31 Hous. L. Rev. 1429, 1446-75 (1995) (noting the additional implications which arise from the tension between religion and health care).

62. Rich, supra note 5 (noting that it was feared that competition might produce redundancy in expensive medical equipment and other inefficiencies and concluding that competition was not beneficial in the health care eontext).

63. 1994 Statements of Enforcement Policy and Analytical Principles Relating to Health Carc and Antitrust, 4 Trade Reg. Rep. (CCH) 13, 152 (Sept. 27, 1994).

64. See Richard A. Feinstein \& David R. Pender, FTC Antitrust Actions in Health Care Services and Products, 1175 PLI/CORP. 261 (2000) (examining the increase in merger challenges).

65. For a thorough overview of recent antitrust decisions in health care industries between 1985 and 1999, see generally Hammer \& Sage, supra note 47.

66. See FTC v. Tenet Healthcare Corp., 186 F.3d 1045 (8th Cir. 1999) (finding that FTC failed to properly define the relevant geographic market and thus failcd to show that the merged entity would enjoy market powcr; also finding that the lower court, which granted an injunction, failcd to consider efficiencies generated by the merger); FTC v. Freeman Hosp., 69 F.3d 260 (8th Cir. 1995) (finding that 
failed to propcrly identify the relevant geographic market. ${ }^{67}$ In other cases, the court found that the government did prove anticompetitive effect but held nonetheless that the gain of efficiencies outweighed the cost of lost competition. ${ }^{68}$ These cases have generatcd a substantial amount of controversy and comment, a large part of which has focused on the courts' treatment of the relevant market analysis. ${ }^{69}$ In other situations, cases are resolved out of court: The government and merging hospitals form an agreement whereby one or both of the hospitals divests certain assets in return for the government dropping antitrust challenges to the merger. ${ }^{70}$ Although these consent agreements are most often precipitated by a desire to settle litigation, they may also be issued before a challenge is brought in court.

In a small but perhaps increasing number of situations, state intervention to regulate the industry will cause the government to abandon the merger challenge. ${ }^{71}$ The government will not pursue mergers that occur under the supcrvision of state regulators because it is presumcd that state supervision will remedy any resulting anticompetitive effects. ${ }^{72}$ Some critics may object to this approach, however, with the argument that the purpose of antitrust law is not only to prevent anticompetitive effects but also to promote competition. Such competition is frustrated when the state

the FTC's failure to establish a valid geographic market and failure to show anticompetitive effects would result from merger warranted denial of the motion for an injunction); United States v. Long Island Jewish Med. Ctr., 983 F. Supp. 121 (E.D.N.Y. 1997) (finding that the government failed to prove that there was reasonable probability of anticompetitive effects and failcd to establish that new anchor hospitals were not likely to cnter the market in response to a price increase); FTC v. Butterworth Health Corp., 946 F. Supp. 1285 (W.D. Mich. 1997) (finding that although the FTC made a prima facie case of lcssened competition, the hospitals successfully rebutted the prima facie case by showing that increased market share does not automatically result in higher prices and that the hospital's nonprofit status and history of community commitment was sufficient to prevent higher prices in the future).

67. See Tenet Healthcare, 186 F.3d at 1053.

68. See, e.g., Butterworth Health, 946 F. Supp. at 1296.

69. See Nicole Harrell Duke, Hospitals Mergers Versus Consumers: An Antitrust Analysis, $30 \mathrm{U}$. Batr. L. Rev. 75 (2000); Hammer \& Sage, supra note 47; Kenneth E. Ycadon, Allowing Large Hospitals to Merge: United States v. Long lsland Jewish Medical Center, 3 DePaul J. Health Care L. 79 (1999).

70. See In re Tenet Healthcare Corp., 123 F.T.C. 1337 (1997); In re Columbia/HCA Healthcare Corp., 120 F.T.C. 743 (1995).

71. See, e.g., Columbus Hosp./Mont. Deaeoness Med. Ctr. Closing Letter, F.T.C. File No. 9510117 (June 28, 1996). This mattcr involved the merger of the only two general acute care hospitals in Great Falls, Montana. The closing letter states that "although the transaction raised significant antitrust concerns, the Commission closed this investigation in light of regulatory involvement by the state of Montana." Id. See also Richard A. Feinstein \& David R. Pender, FTC Antitrust Actions in Health Care Services and Products, 1175 PLI/CORP. 26I, 290-1 (2000) (describing an arrangement between the FTC and the Montana State Department of Justice to drop a pending FTC investigation in exchange for regulatory involvement by the State of Montana).

72. The "state action exemption" to federal antitrust law was identified by the U.S. Supreme Court in Parker v. Brown, 317 U.S. 341, 351 (1943) (holding that Congress, in passing the antitrust laws, did not intend to preempt state economic regulation restraining competition, as long as the restraints constitute "state action or official action directed by a state"). 
permits such consolidation. This argument is supported by evidence of problems involving hospital compliance with state regulations and disputes about how regulations should change when new competitors enter these restricted markets. ${ }^{73}$

Finally, in some cases, the government has prevailed in its challenge and courts have issued a preliminary injunction to prevent a proposed merger ${ }^{74}$ The rarity of these victories reveals how little government challenges have done to alleviate the threat to competition posed by hospital mergers. ${ }^{75}$

The following sections explore several possible reasons for courts' apparent leniency toward hospital mergers. An examination of failed challenges to hospital mergers indicates that antitrust law provides adequate tools for addressing consolidation in the hospital industry but that that courts have misestimated the extent of market power in that industry ${ }^{76}$ and failed to appreeiate the risks posed by the loss of competition in the market. First, courts may overestimate the relevant market, thereby underestimating the effect that a merger will have on price competition. Second, courts may misunderstand the nature of nonprice competition in the hospital industry, erroneously relegating quality and other nonprice considerations to mere afterthoughts, when in reality they are important factors affecting consumer choice. Finally, even when courts recognize that a merger will result in substantial market power for the merged entity, they may rely too often on mitigating factors, such as nonprofit status and community commitment, to control merged entities. Evidence that merged entities are taking advantage of their market power, resulting in increased health care costs and diminished quality of care, shows that courts' antitrust analysis is often flawed.

73. See infra Part IV.A.1.

74. See, e.g., FTC v. Univ. Health, 938 F.2d 1206, 1225 (11th Cir. 199I); United States v. Rockford Mem'l Corp., 898 F.2d 1278, 1286 (7th Cir. 1990).

75. Several other factors also may play a role in the low number of government victories in merger challenges. For example, it is likely that merging hospitals that recognize they have a poor chance of success in a court challenge will be pushed to reach a consent agreement in the first place. Therefore challenges will arise only when merging hospitals feel their case is strong. Thus, in one case, the proposed merger between the only two acute medical centers in a town was abandoned after a suit was filed by the FTC. See FTC v. Local Health Sys., Inc., 120 F.T.C. 732 (1995) (agreeing on a consent order); FTC v. Local Health Sys., Inc., Preliminary Injunction Suit, No. 94 CV 74798 (E.D. Mich. Nov. 30,1994 ) (accepting a consent order which requires FTC approval for three years before parties can make any renewed attempt to merge). Similarly, potentially anticompetitive mergers may be abandoned if the adjudication process takes a long time. The length of the process can be sufficient to allow other deals, more acceptable to the government, to arise. For instance, in FTC v. Hospital Board of Directors of Lee County, 38 F.3d I184 (11th Cir. 1994), the merger was called off because one of the hospitals obtained a better deal while waiting for the conclusion of the court approval process. It is also possible that hospitals with a low likelihood of success in the event of a government challenge might be unlikely to attempt a merger in the first place. It is, however, difficult to gauge the magnitude of this disincentive.

76. See infra Part III.B. 


\section{II}

\section{Introduction to Relevant Antitrust PrinciPles}

\section{A. The Clayton Act}

The principal economic rationale behind antitrust law is that freely operating competitive markets will result in the most efficient allocation of resources and give consumers the widest variety of choices, the best quality, and the lowest prices. ${ }^{77}$ Consequently, antitrust laws aim to protect healthy and vigorous competition from conduct that interferes with the functioning of competitive markets, such as attempts to gain market power or agreements between firms to maintain minimum prices. ${ }^{78}$

The Clayton Act is the primary antitrust statute governing mergers. ${ }^{79}$ section 7 prohibits mergers where the consolidation substantially "lessen[s] competition or ... tend[s] to create a monopoly." ${ }^{, 80}$ In order to establish a prima facie case under the Clayton Act, a plaintiff must demonstrate that the merged entity would enjoy a substantial share of the relevant market, empowering it to raise prices above competitive levels. ${ }^{81}$ The defendants can then rebut this prima facie showing by providing substantial evidence that the merger will create significant efficiencies, which will enhance competition and benefit consumers. ${ }^{82}$ The court must then weigh these competing possibilities and decide whether to enjoin to merger.

\section{B. The Anticompetitive Effects Analysis}

Once the legality of a merger has been challenged, the court must determine whether the proposed merger is likely to generate anticompetitive effects in the market. ${ }^{83}$ An anticompetitive effects analysis involves two

77. See generally Adam Smith, An Inquiry Into the Nature and Causes of the Wealth of Nations (Edwin Cannon ed., 1776).

78. See 15 U.S.C. $\$ 18$ (2000); see also Roger B. Andewelt, Intellectual Property Antitrust-General Antitrust Principles, 685 PLI/PAT. 9 (2001).

79. 15 U.S.C. $\S 18(2000)$. While the mergers considered in this Comment were analyzed under the Clayton Act, it is important to note that other antitrust laws still may apply. In particular, Section I of the Sherman Act makes illegal "every contract, combination in the form of trust or otherwise, or conspiracy, in restraint of trade or commerce among the several States, or with foreign nations." IS U.S.C. $\S 1(2000)$.

80. 15 U.S.C. $\S 18(2000)$.

81. FTC v. Butterworth Health Corp., 946 F. Supp. 1285, 1289 (W.D. Mich. 1997) (detailing the requirements for establishing a prima facie case).

82. FTC v. Univ. Health, Inc., 938 F.2d 1206, 1222 (11th Cir. 1991) (noting that "in certain circumstances, a defendant may rebut the government's prima facie case with evidence that the intended merger would create significant efficiencies in the relevant market'). See also U.S. DEP'T OF Justice \& Federal Trade Commission, Horizontal Merger Guidelines (revised Apr. 8, 1997) $\S 4.0$ ("Efficiencies generated through merger can enhance the merged firm's ability and incentive to compete, which may result in lower prices, improved quality, enhanced serviee, or new products."), available at http:/www.usdoj.gov/atr/public/guidelines/horiz_book/hmgl.html.

83. Courts have defined competition by reference to two different models. The first paradigm of competition emphasizes the number of competitors in the relevant market, while the second focuses on the ability of each market actor to compete vigorously against the others. Although eourts considering 
steps: First, the court must define the "relevant market" that the merger could affect. Second, the court must determine whether the merged entity would have significant market power in this relevant market. ${ }^{84}$

The relevant market is defined by the range of eompetitors who could provide alternative sources for the defendants' services in the event that defendants, as a merged entity, attempt to exercise market power by raising prices above a competitive level. ${ }^{85}$ The two components of the relevant market definition are the product market and the geographic market. ${ }^{86}$ The product market seeks to identify the range of current or potential products that would be able to limit the merged entity's ability to raise prices. ${ }^{87}$ If sufficient alternatives currently or potentially exist in the market, the merged entity will not be able to reduce output and raise the price of its product without generating a compensatory response from other suppliers, which would return prices to competitive levels. ${ }^{88}$ Assume, for example, that a gas station raised prices by $50 \%$ in an attempt to increase profits. Consumers unwilling to pay the higher price would look to the available alternatives. In this scenario, the relevant market might be defined as the group of gas stations within a practical driving distance. If a local garage or automotive supply store had the ability to obtain and sell gas to take advantage of this new group of customers, then this store could be included in the relevant market.

In addition to defining the relevant product market, courts must identify the relevant geographic market, which consists of the actual physical boundaries of the product market. The boundaries of the relevant geographic market are determined by the existence of competitors who are close enough to provide similar products. ${ }^{89}$ The size of the geographic

antitrust claims have deemed both models as proper, in the context of hospital mergers, courts largely have eschewed consideration of the number of competitors in the market and instead have focused on the ability of the hospital to compete with larger entities. For example, in FTC $v$. Freeman Hospital, the court explained that "Oak Hill [Hospital] had been experiencing financial difficulties, and its trustees believed that a merger with Freeman [Hospital] would strengthen Oak Hill's financial standing and enable it to better compete in a changing health care market." 69 F.3d 260, 262 (8th Cir. 1995). Thus, the court gives weight to the likelihood that the merged entity will be a stronger competitor. This analysis furthers the value of competition, despite the fact that a merger would significantly decrease the number of competitors in the market.

84. United States v. Long lsland Jewish Med. Ctr., 983 F. Supp. 121, 136-37 (E.D.N.Y. 1997) (setting out the process of analysis).

85. United States v. Mercy Health Servs., 902 F. Supp. 968, 975 (N.D. Iowa 1995) vacated as moot on unrelated grounds by $107 \mathrm{~F} .3 \mathrm{~d} 632$ (8th Cir. 1997).

86. Freeman Hosp., 69 F.3d at 268.

87. Mercy Health Servs., 902 F. Supp. at 975-76.

88. See FTC v. Staples, Inc, 970 F. Supp. 1066 (D.D.C. 1997) (closely examining the altematives available in the market).

89. See FTC v. Butterworth Health Corp., 946 F. Supp. 1285, 1291 (W.D. Mich. 1996) (noting that in order for the government to meet its burden of proof, "the FTC must present evidence of practical alternative sources to which consumers of general acute care and primary care inpatient 
market is also sensitive to the nature of the product. For example, while a business selling books over the Internet may have competitors across the county, even the world, who actively vie for the same customers, a hospital providing emergency medical care for critically ill patients will face competitors only within a limited geographic range, because critically ill patients will not have time to seek care from hospitals that are farther away. In the context of antitrust enforcement of hospital mergers, determination of the proper geographic market is crucial because courts will not issue injunctions where they feel the government has misconstrued the geographic market. ${ }^{90}$

Correct identification of the relevant market is crucial to predicting and, where possible, quantifying the ability of a merged entity to raise prices above competitive levels. The ability to raise prices above competitive levels is known as market power. Market power is estimated by looking at the effects of the merger within the relevant market, and therefore the definition of the relevant market is crucial for a correct estimation of market power. ${ }^{91}$ Unfortunately, it can be very difficult for a court to make this estimation. For example, in the gas station example discussed above, assume that there were two gas stations in town and one fifty miles out of town. If the two in-town stations tried to merge, a court could define the relevant market as the two in-town stations, in which case the merger would completely destroy competition in that market. But the court could also include the station fifty miles away on the assumption that consumers would travel to that station if the merged entity raised prices too high. If the relevant market includes all three stations, then the effect of the merger on competition seems much smaller. Thus the definition of the relevant market directly affects the estimation of market power.

An important indicator of market powcr is market concentration, which is a function of the number of firms in the market and their respective market shares. The Herfindahl-Hirschman Index ("HHI") is a common mcthod used to quantify market concentration. ${ }^{92}$ The HHI is calculated by squaring the market share of each competing firm and adding the resulting numbers. Under the Federal Trade Commission ("FTC") merger guidelines, a post-merger HHI value above I 800 is deemed to indicate a highly

hospital services would turn if the merger were consummated and the merged entity raised prices beyond competitive levels").

90. See, e.g., FTC v. Tenet Healthcare Corp., 186 F.3d 1045, 1053 (8th Cir. 1999) (finding that "the FTC's failure to prove its relevant geographic market is fatal to its motion for injunctive relief").

91. As Robert Pitofsky explains: "Definition of relevant market is a critical tool in antitrust enforcement because the legality of business conduct almost always depends upon the market power of the participants." Robert Pitofsky, New Definitions of Relevant Market and the Assault on Antitrust, 90 Colum. L. Rev. 1805, 1806-07 (1990).

92. See FTC v. Univ. Health, Inc., 938 F.2d 1206, 1211 n.12 (1lth Cir. 1991); FTC v. PPG Indus., Inc., 798 F.2d 1500, 1502-06 (D.C. Cir. 1986); Butterworth Health, 946 F. Supp. 1285; FTC v. Freeman Hosp., 911 F. Supp. 1213, 1221-22 (W.D. Mo. 1995). 
concentrated market. ${ }^{93}$ A merger that increases the HHI by more than 100 points is deemed likely to create or enhance market power or facilitate its exercise. $^{94}$

While this quantitative approach can be useful in predicting the market power of a merged entity, it is not dispositive. Courts often will consider a host of mitigating factors, such as whether there are other entities poised to enter the market who could decrease market concentration, or whether efficiencies generated by the merger outweigh the risks of anticompetitive effects in the relevant market. Efficiencies in a hospital merger context may include deereased equipment costs and the ability to share staff and facilities. ${ }^{95}$ If the court is persuaded that the benefit of these increased efficiencies outweighs the cost of decreased competition, the court will frequently deny the injunction. Courts also have allowed mergers to proceed where they have determined that the merged entity would not be likely to raise prices because other controls are in place. For example, courts have relied on a hospital's nonprofit status ${ }^{96}$ or its expressed commitment to the community ${ }^{97}$ to regulate prices.

\section{III}

\section{Critique of Courts' Antitrust Analysis}

Antitrust law seeks to respond to actual market realities, rather than to formalistic distinctions. ${ }^{98}$ Thus, it is essential that courts have a proper understanding of market realities in order to apply antitrust law correctly. The accuracy of courts' predictions of these realities rests on correct estimations of the product market and geographic market, which, in turn, require

93. U.S. Dep't of Justice \& Federal. Trade Commission, 1992 Horizontal Merger Guidelines, 4 Trade Reg. Rep. (CCH) 13,104 (revised Apr. 8, 1997), available at http://www.ftc.gov/bc/docs/ horizmer.htm.

94. Id. However, in practice, high $\mathrm{HHI}$ values are not dispositive. See, e.g., Butterworth Health, 946 F. Supp. 1285 (denying an injunction against the proposed merger of two general acute care facilities, even though merger was estimated to increase the HHI by more than $\mathrm{I} 000$ points, representing control of $65-70 \%$ of the market; holding that the nonprofit status of hospital and the "community commitment" gave the merged entity no incentive to exercise market power to raise price).

95. See United States v. Long 1sland Jewish Med. Ctr., 983 F. Supp. 121, 137 (E.D.N.Y. 1997).

96. See, e.g., In re Adventist Health Sys./West, 117 F.T.C. 224 (1994) (finding the acquisition of a for-profit hospital by a nonprofit religiously affiliated hospital system unlikely to have anticompetitive effects, despite the fact that the merged entity would enjoy a $71 \%$ market share).

97. See, e.g., FTC v. Butterworth Health Corp., 946 F. Supp. 1285, 1298 (W.D. Mich. 1996) (considering the value of a "Community Commitment" as a "series of formal assurances ... to assuage any purchaser concerns and to reiterate [the hospitals'] strong conviction that the purpose and intent of the transaction is to reduce costs - and to pass those cost savings on to consumers").

98. See Eastman Kodak Co. v. Image Technical Servs., 504 U.S. 451, 446-67 (1992) (discussing the emphasis on market reality by courts). 
thorough knowledge of the nature of the product and the complexities of consumer behavior. ${ }^{99}$

In the context of hospital mergers, courts often appear to lack this crucial understanding of the industry and consumer behavior. As a result, they may make several fundamental mistakes in their analyses of the anticompetitive effects of hospital mergers: First, the complexities of the hospital industry may lead courts to misconstrue the relevant market. A mistake in defining the relevant market may cause the court to underestimate the merging entity's market power. Second, courts may fail to properly apply quantitative tools in an attempt to quantify the market power that the merged entity would enjoy in the defined relevant market. Third, courts may fail to include important nonprice competition in their analysis of the anticompetitive effeets of the merger. Finally, courts may erroneously allow other factors, such as nonprofit status or the assurance of community control, to mitigate their concerns about lost competition. If a court makes any of these mistakes, the anticompetitive effects of hospital mergers are likely to exceed the court's expectations, and patients are likely to lose the protection against higher prices and lower-quality care that competition can provide.

\section{A. Flaws in the Analysis of the Relevant Market}

The determination of whether a merger will have anticompetitive effects that violate the Clayton Act can depend on how a court defines the relevant market. If the court construes the relevant market broadly, then the merger's anticompetitive effects will appear diminished and the court is more likely to underestimate the merged entity's market power. A correct relevant market definition requires the court to define both the product market and the geographic market. Although defining the product and geographic markets in some industries is relatively straightforward, courts have faced a number of challenges in defining the relevant product and geographic markets in the context of hospital mergers. ${ }^{100}$

\section{Defining the Product Market}

The definition of the product market involves a consideration of the nature of the product, the characteristics of the consumers, and the factors that motivate those consumers' behavior. ${ }^{101}$ In the context of hospital mergers, it may be difficult to define the product market. First, it is not

99. See, e.g., FTC v. Staples, Ine., 970 F. Supp. 1066, 1073-80 (D.D.C. 1997) (considering the extent to which consumer behavior defines the relevant product market).

100. See, e.g., FTC v. Tenet Healthcare Corp., 186 F.3d 1045, 1053-54 (8th Cir. 1999) (examining the relevant markct for hospitals in a sprawling, poorly defined area); Long Island Jewish Med. Ctr., 983 F. Supp. at $137-42$ (considcring a merger where the competitive influences of nearby Manhattan hospitals are unclcar).

101. See Long Island Jewish Med. Ctr., 983 F. Supp. at 137. 
always clear what the product is. The hospital industry is composed of a diverse group of facilities: Some hospitals are small nonprofit entities, while others are part of extensive for-profit hospital networks. Some are affiliated with a particular church and have a strong commitment to charitable care, while others are affiliated with a university and are researchoriented. A hospital may cater to distinct populations within the community or offer women's services that are not offered at other hospitals. ${ }^{102}$ Teaching and research hospitals, or hospitals with a recognized specialty may be thought to offer a superior level of care and thus often draw patients from a very broad geographic area. ${ }^{103}$ By contrast, hospitals that offer emergency services draw patients for those services from a limited geographic area. Moreover, some hospitals offer special surgery centers, or specialized physicians, or high-risk maternity services. For these reasons, there is no standardized notion of hospital product upon which courts can base their analyses. The complex nature of hospitals may obscure the definition of the relevant product market by making it harder to identify both the product offered and the consumer.

In defining the product market when looking at hospital mergers, courts generally have assumed the product to be acute care services. ${ }^{104}$ This definition may be too narrow if it ignores other important services. More importantly, this definition leaves open the question of how a court should handle the diverse nature of hospital services. The FTC has attempted to address this problem by breaking the analysis into two product groups. For example, in FTC v. Butterworth Health Corp., the FTC identified two product markets-general acute inpatient hospital services and primary care inpatient hospital services-and argued that each must be considered separately. ${ }^{105}$ While the Butterworth court declined to adopt the FTC's distinction, ${ }^{106}$ other courts have recognized that multiple products may affect the geographic market, as patients will be more willing to travel for certain services than for others. ${ }^{107}$

Determining the identities of "the consumer" can also be complicated: Is the consumer the individual patient seeking care or the insurance company that contracts with the hospital? ${ }^{108}$ A fundamental confusion

102. See Minow, supra note 28.

103. See Long Island Jewish Med. Ctr., 983 F. Supp. at 141 (noting the attractiveness of specialty and university hospitals to patients and recognizing that patients often travel to obtain specialized care).

104. See, e.g., State v. Sutter Health Sys., 130 F. Supp. 2d 1109, 1119 (N.D. Cal. 2001) (finding that the product market includes "not only services provided by hospitals that offer the full range of general acute inpatient services, but also those [acute care services] available at 'niche' hospitals"); Long Island Jewish Med. Ctr., 983 F. Supp. at 137-40 (defining the product as acute care scrvices).

105. See FTC v. Butterworth Health Corp., 946 F. Supp. 1285, 1290 (W.D. Mich. 1996).

106. Id. at 1291 (identifying "general acute care inpatient hospital services" as the relevant product market).

107. See Long Island Jewish Med. Ctr., 983 F. Supp. at 137-38.

108. Consider also that some patients are insured while others contract directly with the hospital. 
about the structure of the industry might explain why the government and hospital defendants consistently disagree about the anticompetitive impact of a merger. One study found that the government tends to focus on anticompetitive effects at the level where hospitals compete for health plan contracts, while hospitals are more likely to foeus on competition at the level of individual patients. ${ }^{109}$ Both the hospitals and the government may be correct in their assessments of the anticompetitive impact of a merger at the particular level they have focused on, but because of the importance of health plan competition, anticompetitive effects at the health plan level alone are probably sufficient to justify prohibition of the merger. ${ }^{110}$

Onc approach to dealing with this complexity is to regard the industry as a two-tier system, with health plans as the primary consumer and individual patients as the secondary consumer. ${ }^{111}$ This approach suggests that hospitals compete with all hospitals in the area for health plan contracts and at the same time compete against the contracted hospitals for patients. ${ }^{112}$ If this approach reflects the market reality, then without a thorough understanding of this multi-tiered structure, courts are likely to misinterpret the nature of competition between hospitals.

The fact that merging entities may serve different portions of the population makes it even more difficult to understand the impact of the merger on competition. ${ }^{113}$ A merger between hospitals that previously served entirely different patient groups will not directly decrease the competition for these patients because the two hospitals were not really competitors in the first place. However, it is important to remember that even where hospitals were not direct competitors, they still contributed to competition to some degree because they had the potential to provide services if the other hospital raised prices. ${ }^{114}$ The knowledge that patients and health plans have another choice, even if it is less desirable, serves to limit the prices that even the most highly regarded hospitals can charge. Thus, even if the patient populations are different, there may still be some positive effect on competition.

It is also important to consider the degree to which nonhospital entities such as outpatient clinics and doctors' offices produce alternative

109. Gregory Vistnes, Hospitals, Mergers, and Two-Stage Competition, 67 ANTITRUST L.J. 671, $672(2000)$.

110. Id. at 685 .

111. See id. at $684-85$.

112. See $i d$.

113. For example, some hospitals cater to economically disadvantaged portions of the population, while other hospitals in the same area treat wealthier patients. In San Francisco, St. Luke's Hospital provides acute care services to the 340,000 people in the South of Market area, most of whom are poor. Abate, supra note 4 . In contrast, insured or wealthy patients from the same area might be more inclined to seek care at the University of California, San Franciseo, which is a teaching hospital.

114. See United States v. Long Island Jewish Med. Ctr., 983 F. Supp. 121, 149 (E.D.N.Y. 1997) (recognizing the potential for hospitals in nearby Manhattan to enter the market in the future). 
products, thereby broadening the product market. For example, the hospital product of maternity services may also be offered by midwives outside of the hospital. But while some hospital services can be offered by these entities, ${ }^{115}$ other services like acute care and more invasive surgeries remain entirely within the traditional hospital domain. ${ }^{116}$ The fact that the product market can differ depending on the type of product a court is examining makes the analysis very complicated, and it may not be possible for a court to produce one single sufficient product definition.

Finally, consumer behavior may play an important part in defining the product market. Courts have recognized the role that consumer behavior may play in choosing between two otherwise identical products at different stores. In FTC v. Staples, Inc., the district court incorporated evidence of the buying preferences of office supply consumers into the analysis of the product market. ${ }^{17}$ The court concluded that although a stationery store and an office superstore may sell identical office products, people are less likely to make the switch from office superstores to smaller stores even if the superstores raise prices significantly. ${ }^{118}$ The court found that the appeal of superstores like Staples was sufficient to make smaller stationary stores insignificant competitors, and therefore the eourt limited the product market to supplies sold at superstores. ${ }^{119}$

Consumers in the hospital context may exhibit similar behavior: Patients may be less inclined to leave a hospital where their physician practices, regardless of price increases. ${ }^{120}$ While there is a debate over the extent to which patient loyalty to their physician exists and influences a patient's choice of hospital, ${ }^{121}$ evidence of this nature is an important factor in the analysis. Therefore, in looking at a hospital merger, courts should consider what the patients are likely to perceive as viable alternatives.

\section{Defining the Geographic Market}

Estimating the boundaries of the geographic market "to which consumers [of the product] would turn if the merger were consummated

115. See generally United States v. Rockford Mem'l Corp., 898 F.2d 1278 (7th Cir. 1990).

116. Id.

117. 970 F. Supp. 1066, 1073-80 (D.D.C., 1997).

118. Id. at 1080 (finding that "a significant number of superstore customers do not turn to a non-superstore alternative when faeed with higher prices in the one firm markets").

119. Id.

120. Note also that patients are often insulated from the cost of hospital care by insurance, which means that priee is less likely to weaken this bond.

121. See United States v. Mercy Health Servs., 902 F. Supp. 968, 979 (N.D. lowa 1995) (considering the extent to which patient loyalty should factor into the determination of the relevant geographic market, although the court ultimately finds that there was insufficient evidence to assume strong patient loyalty in this case), vacated as moot on unrelated grounds by $107 \mathrm{~F} .3 \mathrm{~d} 632$ (8th Cir. 1997). 
and the merged entity raised prices beyond competitive levels"122 can be just as difficult as estimating the product market for hospital mergers. The court in FTC v. Butterworth Health Corp. noted that determination of the relevant geographic market is a "pragmatic, highly fact-driven undertaking." 123 The burden of proving the geographic market is on the government, ${ }^{124}$ and cases indicatc that this burden has been one of the most significant obstacles to successful government enforcement of antitrust law. ${ }^{125}$

Analysis of the geographic market is typically derived from available patient flow data. ${ }^{126}$ Patient flow data analyzes the zip code of each patient to identify "an area around defendant hospitals (1) from which most of their admitted patients come, and (2) within which most residents remain for hospital care." 127 These regions then comprise the geographic market for purposes of the eourt's anticompetitive effects analysis. This approaeh seems like the most straightforward way to answer the question "where do the patients come from?" However, recent eriticism indicates that patient flow data is misused and that it can lead to overestimation of the geographic market by ignoring many relevant factors, such as the hospital's reputation and doctor affiliation. ${ }^{128}$ These factors may assist courts in determining whether alternative sources of care are actually viable options for patients. ${ }^{129}$ If patients are less likely to switch to another nearby hospital because they feel a strong sense of physician loyalty, then courts need to take this reality into consideration when judging whether other hospitals really represent alternatives.

In general, the failure to consider relevant factors may lead to an overestimation of the geographic market. A broadly defined geographic market will include more potential competitors than a narrowly defined geographic market. Therefore if the court's definition is broader than the reality, the court will think there are more competitors than actually exist.

122. FTC v. Butterworth Health Corp., 946 F. Supp. 1285, 1291 (W.D. Mich. 1996).

123. Id.

124. FTC v. Tenet Healthcare Corp., 186 F.3d 1045, 1052 ("The government has the burden of proving the relevant geographic market").

125. See, e.g., id. at 1053 ("The FTC's failure to prove its relevant geographic market is fatal to its motion for injunctive relief."); Freeman Hosp., 69 F.3d 260, at 268 (finding that the FTC failed to produce evidence addressing practical alternatives for patients of the merging hospitals).

126. See, e.g., Butterworth Health, 946 F. Supp. at 1291-93.

127. Id.

128. Matthew Reiffer, Antitrust Implications in Nonprofit Hospital Mergers, 27 J. LEGIs. 187, 197-201 (2001).

129. These factors suggest that the hospital market has certain imperfections that may obscure a correct understanding of consumer bchavior. See Eastman Kodak Co. v. Image Technical Scrvs., Inc., 504 U.S. 451, 460 (1992) (observing that "[m]arket imperfections ean keep economic theories about how consumers will act from mirroring reality") (quoting Image Technical Serv. v. Eastman Kodak Co., 903 F.2d 612 (9th Cir. 1990)). 
In assuming the presence of these competitors, courts may allow mergers that under a more rigorous analysis would be found to violate antitrust law.

FTC v. Tenet Healthcare Corp. provides a good example of the effect that relevant factors can have on the size of the geographic market. ${ }^{130}$ The district court in Tenet considered the proposed merger of the only two hospitals in a town. ${ }^{131}$ In determining the geographic market, the court considered several factors, including physician loyalty, the fact that the nearest big city hospitals were over an hour drive away, and evidence that patients generally traveled to the larger hospitals only when they needed specialized care not available locally. ${ }^{132}$ From these factors, the court limited the geographic market to a radius of 50 miles, which included 7 hospitals. ${ }^{133}$

On appeal, the Eighth Circuit took a very different approach. ${ }^{134}$ Although the court recognized that these factors may play a role, the court discounted them. ${ }^{135}$ Instead, the court took up the argument that HMOs or insurance companies could "steer" local patients to big city hospitals in response to a local price increase, and thus competition would be maintained. ${ }^{136}$ Under this analysis, the court redefined the geographic market to include 17 hospitals, more than twice the size of the geographic market defined by the lower court. ${ }^{137}$ Courts, therefore, should be acutely aware of the impact that exclusion of relevant factors can have on the overestimation of the relevant market.

\section{B. Underestimation of the Merged Entity's Market Power}

Once the relevant market has been identified, courts use several quantitative tools to estimate the market power a merged entity will have. These tools include the generation of an HHI number, "critical loss analysis," and "critical elasticity of demand." 138 Failure to use these tools properly can generate an underestimation of the merged entity's ability to raise price and, consequently, an underestimation of its market power. ${ }^{139}$ Underestimation of market power impairs a court's ability to recognize when a merger poses a real threat to competition.

The problems with the use of critical loss analysis exemplify how courts can underestimate predicted market power by misapplying quantitative tools. Critical loss analysis estimates the amount of lost sales a firm

\footnotetext{
130. FTC v. Tenet Healthcare Corp., 17 F. Supp. 2d 937 (E.D. Mo. 1998).

131. Id.

132. Id. at $942-5$.

133. Id. at 945 .

134. FTC v. Tenet Healthcare Corp., 186 F.3d 1045 (8th Cir. 1999).

135. Id. at 1049 .

136. Id.

137. Id. at 1053.

138. See James Langenfeld \& Wenqing Li, Critical Loss Analysis in Evaluating Mergers, 46 ANTITRUST Bull. 299 (2001).

139. Id. at 300 .
} 
can tolerate before an increase in prices becomes unprofitable. ${ }^{140}$ Both the government and economists have recently focused on the economic eoncept of "critical loss analysis" to define antitrust markets and evaluate the competitive effects of proposed mergers. ${ }^{141}$ A court will consider the projected financial data for a merged entity and determine what would happen to profits if the merged entity increased prices. If applied properly, critical loss analysis can help determine whether a merger will enable firms to increase price profitably. If misapplied, however, critical loss analysis may underestimate the anticompetitive effects of mergers that actually pose serious risks to consumers. ${ }^{142}$ For this reason it provides a good example of how a misunderstanding of the underlying economics of quantitative measures can have a direct effeet on the outcome of a government challenge. ${ }^{143}$

Courts have made several errors when applying critieal loss analysis. First, some courts have focused solely on the effect of a $5 \%$ price increase on profitability. ${ }^{144}$ The idea is that a hospital with market power will be able to raise prices $5 \%$ without losing profit. Conversely, a hospital without market power will not be able to sustain a $5 \%$ price increase. Thus, where courts found that the merged hospital would not profit from a 5\% price increase, they concluded that the merged hospital would not have market power. ${ }^{145}$ This assumption, however, can be too narrow because it fails to recognize that while this small increase might be unprofitable, a $10 \%$ increase might be profitable. ${ }^{146}$ This oversight is likely to occur in the hospital context where there may be only a small group of patients who are sensitive to price increases. If such a hospital raised prices $5 \%$, it would alienate the small group of price-sensitive patients and experience a loss of profits. If, however, the hospital continued to raise prices, the remaining, less price-sensitive patients might more than compensate for the lost ones, and the hospital would thereby have the ability to increase profits.

There are many reasons why patients may not respond to even a substantial price inerease by taking their business elsewhere. First, demand for certain hospital services, such as emergency care or delivery services, is

140. Id. at 300 .

141. See id. at 328.

142. See id. at 323-32. Langenfeld and Li cited the following cases as examples: United States v. Mercy Health Services., 902 F. Supp. 968 (N.D. lowa 1995), vacated as moot on unrelated grounds by 107 F.3d 632 (8th Cir. 1997); FTC v. Tenet Healthcare Corp., 186 F.3d 1045 (8th Cir. 1999); State v. Sutter Health System, slip. op. (N.D. Cal. Jan. 5, 2000). Id. at 324.

143. See id.

144. See, e.g., Tenet Healthcare, 186 F.3d at 1049-53; State v. Sutter Health Sys., I30 F. Supp. 2d 1109,1129 (N.D. Cal. 2001).

145. See, e.g., Sutter Health Sys., 130 F. Supp. 2d at I128-29.

146. For example, in Sutter Health Sys., 130 F. Supp. 2d at 1129, the court narrowly focused on a $5 \%$ increase, ignoring the government's assertion that a $10 \%$ price increase could be profitable. See Langenfeld \& $\mathrm{Li}$, supra note 138 , at 310-12. 
relatively inelastic because patients are much less willing to travel greater distances to obtain these services. Relatively inelastic demand for the product indicates that the actual loss of patients or health plan contracts would be small even if a merged entity chose to increase prices. ${ }^{147}$ This concept is especially relevant in the hospital industry, where acute care services are typically not optional. For example, someone with a gunshot wound must receive immediate medical attention. If there is only one hospital in the area, the fact that this hospital has raised prices will not deter the gunshot victim from using its services. Second, patients may be unwilling to use a hospital where their physician does not have admitting privileges. Third, insured patients may not be cognizant of the charges at different hospitals. For all of these reasons, courts may miss valuable information when they fail to consider the profitability of a price increase larger than $5 \%$.

Another error that courts have made concerns the estimation of lost sales. Commentators point out that courts often fail to account for the amount of lost sales that will be recouped if a patient switches to another hospital that is part of the same network. ${ }^{148}$ It is possible for a hospital network to raisc prices at one hospital while cxperiencing no net decrease in the number of patients. ${ }^{149}$ For example, a hospital that raises prices may lose some patients to the other hospital in town. But if the other hospital in town is owned by the same hospital network as the first hospital, then the network has not experienced any net loss. Commentators suggest that this phenomenon was at work in FTC $v$. Tenet Healthcare Corp.: Each hospital "would have been at [its] break-even critical loss level prior to the merger." 150 In this situation, a further price increase by the individual hospitals would havc been unprofitable, but only barely unprofitable. But as a merged entity, the hospital network would be able to recover the lost profit on those patients who switch between the two hospitals. The merged entity, therefore, would have the ability to raise prices without experiencing a net loss.

Finally, it is important to recognize the impact that a hospital merger can have on the pricing behavior of competitors: If the merged entity raises prices, non-merging competitors will have the opportunity to increase their prices without losing patients. ${ }^{151}$ Therefore, the merging hospital will not necessarily lose a significant number of patients by raising prices because the lower-cost alternatives may no longer exist. Merging entities may thus have greater power to raise prices than courts realize. It is

147. Langenfeld \& Li, supra note 138 , at 310 .

148. Id. at 314. Langenfeld and Li used Tenet Healthcare, 186 F.3d 1045, and Sutter Health, 130

F. Supp. $2 \mathrm{~d} 1109$, to illustrate how courts make this error.

149. Id.

150. Id. at 328. See also Tenet Healthcare, 186 F.3d 1045.

151. Langenfeld \& Li, supra note 138, at 317-23. 
important for courts applying a critical loss analysis-or any other quantitative tool-to take these market realities into consideration in order to accurately predict the merged entity's ability to raisc prices.

\section{Failure to Include Nonprice Competition in Analysis}

Whether using critical loss analysis, $\mathrm{HHI}$, or any other quantitative tool, courts may ignore the reality of nonprice competition between hospitals. Hospitals do not compete simply on the basis of price alone, whether for insurance contracts or for patients. Patients are likcly to consider nonprice factors such as reputation, quality of care, physical appearance of the hospital, and other bonuses like private rooms or outpatient clinics. ${ }^{152}$ Health plans feel the impact of nonprice competition to the extent that patients will prefer health plans that include access to better hospitals. In some situations, a hospital may be such an "essential facility" that no health plan will be successful if it fails to offer access. ${ }^{153}$ Additionally, the fact that many patients are insured and therefore somewhat insulated from price consideration, supports the idea that nonprice factors may affect substantially patient choice.

Consolidation may affect nonprice factors in the same way that price competition is often affected: If a hospital has no incentive to attract and maintain patients, what will prevent that hospital from allowing quality of care to slip? ${ }^{154}$ In fact, there is evidence that the cost savings attributed to some mergers are actually the result of the merged entity cutting nonprice services. ${ }^{155}$ These reductions in quality may be acceptable as a matter of health care policy, but courts should not discount the social value of nonprice services under the pretext that nonprice considerations are not relevant in antitrust analysis. ${ }^{156}$ The court in United States v. Mercy Health Services, for example, did not recognize the value of nonprice competition, holding that the government failed to show that nonprice amenities improve the quality of health care received by patients. ${ }^{157}$ The court substituted "its own judgment concerning the proper allocation of social resources" for a correct analysis of the antitrust legality of the merger. ${ }^{158}$

152. See Vistnes, supra note 109.

153. See Gaynor, supra note 30 (defining the children's hospital as an "essential facility" and arguing that the facility greatly enhanced UPMC's market power).

154. Of course, there are minimum standards of care imposed by health and safety regulations. The question then becomes whether we are satisfied with government regulation of hospital standards or whether we believe patients deserve the higher levels of care which competition can promote.

155. See Peter J. Hammer, Questioning Traditional Antitrust Presumptions: Price and Non-Price Competition in Hospital Markets, 32 U. MICH. J.L. ReFORM 727, 753-55 (1999) (suggesting that mergers decrease costs by decreasing the provision of nonprice services).

156. Id. at 755-56 (arguing that courts fail to determine the value of nonprice factors).

157. Id. at 759 (arguing that the court in Mercy Health Servs. failed to appreciate the detrimental effects of reducing nonprice competition).

158. Id. 
The role of competition in fostering higher quality and lower prices is frustrated when courts fail to give proper weight to the true value of nonprice factors as they affect competition in the market. Therefore, an analysis that fails to give weight to the value of nonprice factors misses an important part of the competitive interaction between hospitals.

\section{Overestimation of Mitigating Factors}

Some courts have concluded that a defendant can rebut a prima facie case of a Clayton Act violation with evidence showing that the merger would generate efficiencies, ${ }^{159}$ thereby mitigating any anticompetitive effects. In particular, courts dismiss the dangers of consolidation when the hospitals involved are nonprofit or part of a community-control system. These mitigating factors can be easily overvalued by courts and are rarely sufficient to compensate for the negative impact of the merger on competition.

\section{Nonprofit Status}

It is generally agreed that nonprofit status, per se, does not exempt an entity from antitrust laws: "The significance of 'not-for-profit' status in a section 7 Clayton Act case is unclear," but "there are persuasive precedents that have declined to give any effect to such status." 160 However, in the hospital context, although there is no per se exemption, courts seem willing to give substantial weight to nonprofit status as a mitigating factor. The issue then is whether there is something unique to the hospital industry that warrants special antitrust treatment of nonprofit hospitals. One argument that has been persuasive to some courts is that nonprofit hospitals have no incentives to raise price, and therefore, a nonprofit merger will not harm consumers. ${ }^{161}$ Courts have also held that nonprofit status can be considered as a mitigating factor if supported by evidence such as a tradition of providing free care to the poor. ${ }^{162}$

159. See, e.g., FTC v. Univ. Health, 1nc., 938 F.2d 1206, 1222 (11th Cir. 1991).

160. United States v. Long lsland Jewish Med. Ctr., 983 F. Supp. 121, 145-46 (E.D.N.Y. 1997) (referring to NCAA v. Board of Regents, 468 U.S. 85, $101 \mathrm{n} .23$ (1984) (stating that "good motives will not validate an otherwise anti-competitive practicc")). See also Am. Soc'y of Mech. Eng'rs, Inc. v. Hydrolevel Corp., 456 U.S. 556, 576 (1982) (stating that "it is beyond debatc that nonprofit organizations can be held liable under the antitrust laws"); Unitcd States v. Brown Univ., 5 F.3d. 658, 665 (3d Cir. 1993) (stating that "the absence of profit is no guarantee that an entity will act in the best interest of consumers").

161. See FTC v. Butterworth Health Corp., 946 F. Supp. 1285, 1297 (W.D. Mich. 1996) (finding that "a substantial incrcase in market concentration among nonprofit hospitals is not likely to result in price increases").

162. See id. at 1296 (interpreting precedent as implying "openness to considering nonprofit status as a rclevant consideration if supported by other evidencc that anticompetitive effects would not be produced"); United States v. Carilion Health Sys., 707 F. Supp. 840 (W.D. Va. 1989) (considering nonprofit status as well as a tradition of giving free care to the poor as evidence that the mergcd entity would not increase prices). 
There is some evidence that nonprofit entities are less likely to raise prices. For example, a study by William J. Lynk ("the Lynk study") tested the Department of Justice's claim that hospital ownership status did not affect the relationship between market concentration and price. ${ }^{163}$ The Lynk study has been widely cited by courts when considering the significance of nonprofit status to antitrust analysis of hospital mergers. ${ }^{164}$ Lynk found that nonprofit hospitals were not likely to raise prices: "Relative to for-profit hospitals, private nonprofit hospitals in this sample have a significantly lower association between higher market shares and higher prices, and on balance increased nonprofit market share is associated with lower, not higher, prices." 165 Implicit in this study is the idea that nonprofit entities are insulated from the corrupting influence of profit and therefore less likely to take advantage of market power to raise prices. However, there is evidence that merged nonprofit entities have raised prices after a merger; accordingly, nonprofits do not deserve special exemption under antitrust law. ${ }^{166}$

Results of a recent study by Young, Desai and Hellinger also cast doubt on the Lynk study. ${ }^{167}$ This study found that "when conditions existed to create a more concentrated market, (1) all ... types of nonprofit hospitals exercised market power in the form of higher prices, and (2) hospitals that were members of nonlocal systems were more aggressive in exercising market power than were either independent or local system hospitals." 168 The results of this latest study comport with common sense: If the alleged financial pressures in the hospital industry are true, what othcr than competition (aside from the possibility of community control) prevents hospitals from raising prices? Nonprofit hospitals could be tempted to increase prices in order to lessen their financial burdens, or even to be better able to respond to the indigent population. As one court has acknowledged, there is nothing "inherent in the structure of the corporate board or the nonprofit status of the hospitals which would operate to stop any anticompetitive behavior." ${ }^{169}$ For these reasons, courts

163. William J. Lynk, Nonprofit Hospital Mergers and the Exercise of Market Power, 38 J.L. \& ECoN. 437 (1995) (responding to the Antitrust Division's statement that "[b]oth common sense and economic theory demonstrate that the competitive behavior and financial performance of nonprofit hospitals-including the incentive to raise priees when faced with less competition-will not differ materially from investor-owned hospitals"); Robert E. Bloch, Antitrust Enforcement and Health Care: On the Cutting Edge, Address before the National Health Lawyers Association, (January 27, 1989)).

164. See, e.g., FTC v. Butterworth Health Corp., 946 F. Supp. 1285, 1295 (W.D. Mieh. 1996); United States v. Rockford Mem'l Corp., 717 F. Supp. 1251, 1268 (N.D. 111. 1989).

165. Lynk, supra note 163 , at 459.

166. See generally Hammer, supra note 155 .

167. See Young et al., supra note 27, at 1054 (finding that nonprofits actually do raise prices, especially where community control is absent or weak).

168. Id. at 1051.

169. United States v. Mercy Health Servs., 902 F. Supp. 968,989 (N.D. Iowa 1995) vacated as moot on unrelated grounds by 107 F. 3d 632 (8th Cir. 1997). 
should not accord substantial weight to nonprofit status as a mitigating factor.

\section{Post-merger Community Control}

Community control is the idea that local people with control over the decisions a hospital makes will make decisions that best serve the interests of the community. In the context of antitrust enforcement, community control has been offered by merger advocates as a reason why a merged entity will not raise prices or decrease quality despite having substantial market power. ${ }^{170}$ Implicit in this idea are the assumptions that hospital managers with local ties will remain faithful to their community even after acquiring market power and that the merged entity will not replace these local sympathizers with outsiders. There is some support for this theory: The Young, Desai, and Hellinger study found that "[w]here community control is absent or weak, nonprofit hospitals may be inclined to exercise market power in the form of higher prices." ${ }^{\prime 71}$ Conversely, it seems that where community control is functioning properly, there may be less need for antitrust scrutiny of mergers.

However, the Young, Desai, and Hellinger study also found that "community control is likely to be attenuated for hospitals that through merger or acquisition become members of hospital systems." 172 The government made this same point in Butterworth Health Corp., producing evidence that board members quickly develop institutional loyalty that may overcome their vigilance in defense of community interests. However, the court ultimately held that while it did not "dismiss the [government's] concerns as unreasonable or unfounded... on balance, [they are] unpersuasive." 173 Even if courts believe that a community commitment is likely to protect the public in the near future, they should recognize that the resulting consolidation is likely to persist for a long time, leaving patients vulnerable to any future decrease in community commitment.

\section{IV}

\section{The Need for Stricter Antitrust Analysis}

\section{A. The Continued Role of Courts}

The courts' crucial role in enforcing antitrust law is not likely to end anytime soon. The number of planned mergers is expected to increase in

170. See FTC v. Butterworth Health Corp., 946 F. Supp. 1285, 1298 (W.D. Mich. 1996).

171. Young et al., supra note 27, at I059.

172. Id. at 1054 . There are many possible explanations for the attenuation of community control, but one of the most obvious is the change in focus from a small community-based operation to a larger (and often more profit-oriented) hospital system.

173. Butterworth Health, 946 F. Supp. at 1297. 
the future, ${ }^{174}$ and the number of challenges is also likely to increase: The FTC raised its spending on antitrust probes in the health care industry by $50 \%$ in $2002,{ }^{175}$ and the agency plans not only to investigate new mergers but also to reevaluate past mergers that may have resulted in anticompetitive price increases. ${ }^{176}$ Nevertheless, some commentators believe that this increase in antitrust challenges is unlikely to chill any future deals for the nation's largest hospital consolidators. ${ }^{177}$ Given the continued significance that mergers will play in the hospital industry, it is clear that such mergers must be subject to stricter scrutiny.

\section{B. Alternatives to Judicial Action}

The following sections evaluate alternatives to judicial action and conclude that courts are in the best position to ensure competition if they apply antitrust law in a way that avoids the pitfalls identified in this Comment.

\section{State Regulation of Hospital Mergers}

Recognizing the obstacles that the government currently faces in winning merger challenges, commentators have suggested that state regulation of hospitals might be a good alternative to federal antitrust enforcement. ${ }^{178}$ Indeed, the FTC has declared that where states are willing to regulate the industry and supervise the activity of the merged entity, the government will drop any pending antitrust challenges and defer to the state. ${ }^{179}$ While some states have taken this approach, ${ }^{180}$ the ultimate success of state regulation is unclear.

Several problems exist with state regulation of hospital mergcrs. First, state regulation necessitates ongoing state involvement with the industry.

174. See, e.g., Spetz et al., supra note 4 , at 228 (stating that the number of mergers in California is expected to increase).

175. Reed Abelson, U.S. to Step up Antitrust Effort on Health Care, N.Y. Times, Aug. 9, 2002, at Al (quoting the chairman of the FTC).

176. See, e.g., Mark Cecil, FTC Task Force Puts Hospital M\&A on Notice, Mergers \& ACQUiSITIONS REP., Sept. 9, 2002.

177. Id.

178. See, e.g., Gaynor, supra note 30 (considering the hospital industry and concluding that "[e]ffective markets require regulation in order for them to work"). But see William M. Sage \& Peter J. Hammer, A Copernican View of Health Care Antitrust, 65 Law \& Contemp. Probs. 241 (2002) (advocating abandonment of the active state supervision requirement and instead arguing for the subjection of regulation to substantive antitrust scrutiny).

179. See, e.g., Columbus Hosp./Mont. Deaconess Med. Ctr. Closing Letter, F.T.C. File No. 9510117 (June 28, 1996).

180. Montana, for example, regulates the terms of a state-authorized monopoly. See generally Mark Taylor, Benefis Tries Again: New Competitor Spurs Mont. System to Seek Further Relief From Merger Rules, 31 MOD. HEALTHCARE 39 (2001). North Carolina has taken a similar approach. See Jean Fisher, FTC Probing Hospital Mergers, The News and Observer (Raleigh, N.C.), Dec. 23, 2002, at Al. 
States may be forced to continuously monitor the financial activity of a merged entity and ensure compliance with the terms of any agreements. ${ }^{181}$ This process is expensive and may give rise to other issues, such as what role the state should play in controlling the entry of future competitors into the market, ${ }^{182}$ or whether a state should allow merged entities to change the terms of their agreement in response to changed market conditions. ${ }^{183}$ While states commonly perform regulatory functions, there may not be adequate incentive for the states to take on such a laborious role when antitrust laws already are enforced by the federal government.

Second, state regulation nccessitates an investment of state administrative rcsources. Some states may not experience a sufficient return on their investment of regulatory effort: For example, in the case of Montana's state-authorized monopoly, initially projected cost savings have decreased by more than $40 \%$ so far, even as the hospital's profits increased by $\$ 9$ million in $1999 .{ }^{184}$ Another consideration is that many states lack the expertise or staff to effectively administer necessary supervision. ${ }^{185}$ This may explain why the hospital industry has not seen substantial state regulatory involvement. Given these realities, the cost of enforcement and litigation must be considered when judging the benefits of state regulation of mergers. For these reasons, state regulation does not appear to be a likely substitution for eourt enforcement of antitrust law.

\section{Cooperative Efforts Between Hospitals}

Some hospitals have tried to gain the benefits of a merger without actually merging by forming cooperative arrangements. ${ }^{186}$ In a cooperative arrangement, two hospitals might share expensive pieces of equipment or a billing department in an effort to minimize operating costs. ${ }^{187}$ In one example, two hospitals in Poughkeepsie, New York, coordinated their operations by organizing the joint provision of new services, including clinical

181. Id.

182. Benefis Healthcare returned to the Montana attorney general to ask for "further concessions, not only because of onerous conditions of the antitrust agreement but because it will no longer hold a monopoly" once a new competitor enters the market. Id. at 40.

183. Benefis Healthcare sought relief from restrictive elements of the covcnant, saying the conditions imposed were "hurting its profitability and could lead to its demise." Id. at 39.

184. Id.

185. See Blair Gifford, New Factors in the Antitrust Regulation of Hospital Mergers, J. HealthCare Mgmt. 367 (Sept. 7, 1999).

186. See Cinda Becker, $A$ Matter of Definition: Two Hospitals Sue State Over Nature of Proposed Action, 30 MOD. HEalthCaRe 16, 16 (2000) (describing the effort of two hospitals "to keep the 'M' word out of thcir proposed deal"); Thomas H. Brock, Scrutinizing Hospitals' "Virtual Mergers, " NEw YoRK L.J., July 2, 2001, at 7 (noting that in transactions known as "virtual mergers," two hospitals "partially combine their management, finances and other aspects of their operations, yet retain some independencc").

187. Id. 
services. ${ }^{188}$ While they shared the profits from this joint venture, they did not integrate their businesses. ${ }^{189}$ Despite the efficiency arguments made by both parties, a court found that the jointly negotiated contracts and rates constituted a per se violation of antitrust laws. ${ }^{190}$ The difference between this result and the leniency generally enjoyed by merging entities under the Clayton Act can be explained by the fact that cooperative efforts are subject to scrutiny under the Section 1 of the Sherman Act, which proscribes "every contract, combination in the form of trust or otherwise, or conspiracy, in restraint of trade or commerce among the several States, or with foreign nations." 191 The concern is that by forming a cooperative arrangement, two hospitals may be able to set minimum prices or engage in other anticompetitive behavior. Thus, the ability of hospitals to cut costs in this manner is therefore limited by the threat of an antitrust investigation by the government. ${ }^{192}$ For this reason, it is appears that cooperative arrangements are limited as viable alternatives to merging.

\section{CONCLUSION}

The incentive for hospitals to merge is understandable, whether as a response to financial pressures, as a means to become a stronger competitor, or as a way to gain negotiating clout with enormous insurance and pharmaceutical forces. It is true that mergers may provide important benefits for the hospital in terms of cost savings and increased efficiency. The problem is that the purpose of antitrust law is not to protect the merging cntities; the purpose of antitrust law is to protect consumers from the anticompetitive effects of mergers.

Consumers are not always protected when courts allow hospitals to consolidate. If a merging entity enjoys substantial market power, or has an essential facility, consumers may have no alternative source of care if the hospital chooscs to raise prices or decrease care. This may be especially true if there is no entity supervising hospital practices and pricing after a

188. Id.

189. Id.

190. Id. (referring to New York ex rel. Spitzer v. Saint Franeis Hosp., 94 F. Supp. 2d 399 (S.D.N.Y. 2000)). See also Kowalczyk, supra note 25.

191. 15 U.S.C. $\S 1(2000)$. See supra Part 1.B.1 (discussing the antitrust liability associated with collaboration between hospitals).

192. This limitation becomes especially apparent when considering the potcntial financial penalties:

Every person who shall make any contract or engage in any combination or conspiracy hercby declared to be illegal shall be deemed guilty of a felony, and, on conviction thereof, shall be punishcd by fine not exceeding $\$ 10,000,000$ if a corporation, or, if any other person, $\$ 350,000$, or by imprisonment not exceeding thrce years, or by both said punishments, in the discretion of the court.

15 U.S.C. $\$ 1(2000)$ 
merger. ${ }^{193}$ And once consolidation has occurred, the barriers to entry are usually sufficient to ensure that power over price will persist.

Instead of continuing to take a lenient approach, courts should be more stringent in their treatment of hospital mergers. In the absence of reasonable alternatives to judicial scrutiny of hospital mergers, it is especially important for courts to apply antitrust law correctly to hospital merger challenges. To this end, courts should pay close attention to the complexities involved in defining the relevant market in each case. When considering the product market, courts should recognize that hospital products may need to be individually identified before the court can assess the range of products at issue. Courts also should recognize the role that consumer behavior plays in determining which services are adequate alternatives. When considering the geographic market, courts should sensitive to the nature of the product. For example, heart attack victims are much less likely to travel for care if immediate attention is available at a local hospital, regardless of price. On the other hand, someonc seeking an elcctive procedure like cosmetic surgery is much more likely to consider hospitals or providers in a much broader geographic area.

Further, courts need to be very careful in estimating a mcrged entity's market power. If they use quantitative tools like HHI or critical loss analysis, they should be cognizant of the fact that incorrect application of these tools can lead to a misunderstanding of actual market power. And, when courts consider the anticompetitive cffects of mcrgers, it is important that they take a closer look at the true nature of competition between hospitals over nonprice factors, such as quality of care and nurse/patient ratios.

Finally, courts should not overvalue mitigating factors such as nonprofit status and community control. The idea that these factors will generate sufficient price and quality protection for consumcrs is appealing in theory, but it seems to fall short in reality. Therefore, courts should not place much, if any, weight on these factors.

If courts are sensitive to the complexities and pitfalls of analyzing the anticompetitive potential of a merger, then antitrust enforcement of hospital mergers will improve, and consumers will receive the protection they deserve. ${ }^{194}$

193. It is possible for the government to challenge a merger once it has already occurred. However, this post-merger option is not necessarily an adequate alternative to preventing such mergers from taking place. First, the government may not have the time, resources, or inclination to pursue a challenge once the merger is completed. Second, the challenge may not be successful for many of the same reasons that pre-merger challenges are not often successful.

194. Although bcyond the scope of this Comment, it is important to note that a stricter application of antitrust law could have ramifications for all health eare industries. Stricter antitrust enforcement would send a signal to other scctors of the health care industry that courts will no longer make special exceptions under antitrust law. If mergers ccase to be an easy route for health care entities (whether hospitals, physicians, or others) looking for efficiencies and bargaining power, they could be forced to turn to the national legislature for answers. Considering the uniquely interrelated nature of hcalth care 
